\title{
Effects of concentrated growth factors on the angiogenic properties of dental pulp cells and endothelial cells: an in vitro study
}

\section{Huan JUN(a) \\ Dou LEI(a) \\ Yan QIFANG(a) \\ XU YUAN(a) \\ Yang DEQIN(a)}

(a)Chongqing Medical University, College of Stomathology, Chongqing, China.

Declaration of Interests: The authors certify that they have no commercial or associative interest that represents a conflict of interest in connection with the manuscript.

Corresponding Author:

Yang Deqin

E-mail: yangdeqin@gmail.com

hitps://doi.org/10.1590/1807-3107bor-2018.vol32.0048

Submitted: January 16, 2018

Accepted for publication: April 10, 2017

Last revision: April 23, 2018

\begin{abstract}
The aim was to investigate the angiogenic effects of concentrated growth factors on human dental pulp cells and human umbilical vein endothelial cells. Cells were treated with concentrated growth factor extracts. The CCK-8 assay and cell cycle assay were conducted to evaluate cell growth. Cell migration was evaluated by the Transwell migration assay. Angiogenesis-associated mRNA and protein expression levels were determined using quantitative real-time PCR and Western blotting, respectively. A tube formation assay was conducted to evaluate the angiogenic capacity in vitro. The data showed that compared with the control, concentrated growth factor extracts significantly promoted dental pulp cell proliferation and differentiation and endothelial cell proliferation and migration in a dose-dependent manner $(p<0.05)$. Concentrated growth factor extracts also promoted the tube-like structure formation of endothelial cells in vitro. The RT-PCR and Western blot results showed that concentrated growth factor extracts upregulated the expression of angiogenesis-related genes - chemokine receptor-4, platelet-derived growth factor, and vascular endothelial growth factor - in dental pulp cells. In conclusion, concentrated growth factors showed proangiogenic effects on dental pulp cells and endothelial cells and have good application potential for dental pulp revascularization.
\end{abstract}

Keywords: Endothelial Cells; Endodontics.

\section{Introduction}

Dental pulp revascularization has been widely applied in dental clinics and has been demonstrated to promote the continuous root development of necrotic immature teeth. ${ }^{1,2,3}$ The formation of a high-quality blood clot in a root canal was considered a key point in dental pulp revascularization. The blood clot acts as a biological scaffold for regenerative endodontic treatments and affects the prognosis of treated teeth. ${ }^{4,5}$ However, in some cases, high-quality blood clots cannot be formed in the root canal space, which may lower the success rate of pulp revascularization. ${ }^{6}$ In recent years, platelet concentrates have been used as scaffold materials to compensate for the lack of high-quality blood clots and to increase the success rate. ${ }^{7,89}$ 
Currently, new generations of platelet concentrates are being developed and applied in the dental clinic. Concentrated growth factor (CGF), the newest product, contains abundant growth factors, such as platelet-derived growth factor (PDGF), chemokine receptor 4 (CXCR4), vascular endothelial growth factor (VEGF), fibroblast growth factor, and insulin-like growth factors..$^{10}$ In addition, CGF lacks the cell components of whole blood, avoiding the risk of infectious disease. CGF represents natural scaffolds with the potential to accelerate tissue repair, ${ }^{.112}$ therefore, we speculated that CGF can improve the prognosis of dental pulp revascularization. A key factor is that newly formed blood vessels grow into the root canal and provide oxygen and nutrients for dental pulp revascularization. However, the angiogenic effects of CGF on dental pulp revascularization are rarely discussed. Thus, the present study aimed to evaluate the angiogenic effects of CGF on dental pulp cells(DPCs) and endothelial cells at the cellular and molecular biological level.

\section{Methodology}

\section{Preparation of concentrated growth factor extracts (CGFe)}

This study was approved by the Institutional Research Ethics Committee of Chongqing Medical University, Chongqing, China (4th April, 2016; CQHSIRB-2016-04), and informal consents were acquired from donors. Venous blood was obtained from three healthy, nonsmoking male volunteers (age range of 35-40 years). As described in a previous study, ${ }_{1}^{13}$ peripheral blood was collected and immediately centrifuged by a Medifuge centrifugation system (Silfradent, Italy). CGF clots isolated from the three blood samples were mixed, placed on gauze to eliminate excess serum and transferred to freezing tubes. CGF clots were minced, homogenized, stored at $-80^{\circ} \mathrm{C}$ for $1 \mathrm{~h}$, and then centrifuged at $3000 \mathrm{rpm}$ for $10 \mathrm{~min}$ at room temperature. The supernatants (CGFe) were filtered by a $0.22 \mu \mathrm{m}$ sterile syringe filter (Solarbio, China) and then stored at $-80^{\circ} \mathrm{C}$ until use. The final CGFe concentration $(2 \%, 5 \%, 10 \%$ and $15 \%)$ in the experimental groups was calculated on the basis of the volume of CGFe that was added to the total volume of culture medium containing $10 \%$ fetal bovine serum (FBS). The control group only received 10\% FBS.

\section{Cell culture}

Human umbilical vein endothelial cells (HUVECs) were purchased from Chongqing Baersi Biotechnology Corporation and were cultured in Dulbecco's modified Eagle's medium (DMEM) with 10\% FBS containing $100 \mathrm{U} / \mathrm{mL}$ penicillin and $100 \mathrm{mg} / \mathrm{mL}$ streptomycin in a cell incubator at $5 \% \mathrm{CO}_{2}$ and $37^{\circ} \mathrm{C}$.

DPCs were isolated from the premolars of a 13-yearold patient that were extracted for orthodontic purposes using the method described by Ma et al. ${ }^{14}$ Only 5 th generation dental pulp cells were used for experiments. The cells were cultured in DMEM (high glucose) with $10 \%$ FBS containing $100 \mathrm{U} / \mathrm{mL}$ penicillin and $100 \mathrm{mg} /$ $\mathrm{mL}$ streptomycin in an incubator at $37^{\circ} \mathrm{C}$ and $5 \% \mathrm{CO}_{2}$.

\section{Cell proliferation assay}

Cells (DPCs and HUVECs) were seeded in a 96-well plate at a density of $3 \times 10^{3}$ cells per well and treated with different concentrations of CGFe or FBS. After culturing for $0 \mathrm{~h}, 12 \mathrm{~h}, 24 \mathrm{~h}$, and $36 \mathrm{~h}$ at $37^{\circ} \mathrm{C}$ and $5 \%$ $\mathrm{CO}_{2}$, the cell proliferation rates were determined with CCK-8 (Solarbio, China) using a microplate reader (Bio-Rad, Hercules, USA) at a wavelength of $450 \mathrm{~nm}$. Eight repetitive wells were used for each group, the maximum and minimum values were excluded, and the remaining data were used for statistical analysis.

\section{Cell cycle analysis}

DPCs were seeded in a 6-well plate at a density of $2 x$ $10^{5}$ cells per well. After overnight serum starvation, the DPCs were incubated in a cell incubator and treated with different concentrations of CGFe or FBS for $24 \mathrm{~h}$. Then, the DPCs were fixed with precooled $70 \%$ ethanol at $4{ }^{\circ} \mathrm{C}$ overnight. The cell cycle was evaluated using a cell cycle kit (Solarbio, China) according to the manufacturer's instructions. Cell samples were analyzed by flow cytometry (BD, USA), and data were analyzed using Modfit LT 4.1 software (Verity Software House, USA).

\section{Transwell migration assay}

A migration assay was performed using a 12-well Transwell chamber plate ( $4 \mu \mathrm{m}$ pore size, Corning) following the manufacturer's protocol. HUVECs were seeded in triplicate in the upper compartment of the chamber $\left(10 \times 10^{4}\right.$ cells $/ 500 \mu 1$ per well). The lower compartment was filled with $1.5 \mathrm{~mL}$ of cell culture 
medium containing different concentrations of CGFe or FBS. After culturing for $6 \mathrm{~h}$ at $37^{\circ} \mathrm{C}$ and $5 \% \mathrm{CO}_{2}$, the cells that migrated through the polycarbonate membrane were fixed with methanol for $20 \mathrm{~min}$ and then stained with crystal violet for $15 \mathrm{~min}$. The cells were photographed under a microscope with a digital imaging system (Nikon, Japan) and counted.

\section{In vitro tube formation assay}

Matrigel (BD, USA) was thawed at $4^{\circ} \mathrm{C}$ overnight and then coated on the bottom of a 96-well plate (50 $\mu \mathrm{l}$ per well) at $37^{\circ} \mathrm{C}$ for $1 \mathrm{~h}$. The endothelial cells (1X10 cells/200 $\mu 1$ per well) suspended in medium containing different concentration of CGFe or FBS were added to the matrigel and cultured at $37^{\circ} \mathrm{C}$ and $5 \% \mathrm{CO}_{2}$ for $4-18 \mathrm{~h}$. Vessel tube-like structures were observed and photographed under a microscope with a digital imaging system (Nikon, Japan). Then, the data were analyzed using ImagePro Plus software.

\section{Quantitative real-time PCR}

Total RNA was isolated from DPCs using RNAiso plus reagent (Takara, Japan). cDNA was synthesized by the use of a RevertAid Reverse Transcription Kit (Thermo Scientific, China) and then analyzed by the use of a real-time PCR system (Bio-Rad, USA). The reaction conditions were as follows: preannealing at a temperature of $9{ }^{\circ} \mathrm{C}$ for $30 \mathrm{~s}$; annealing at temperatures of $95^{\circ} \mathrm{C}$ for $5 \mathrm{~s}$ and $6{ }^{\circ} \mathrm{C}$ for $34 \mathrm{~s}$ for 40 cycles. Expression values were normalized to GAPDH. The sequences of CXCR4, PDGF, VEGF and GAPDH are detailed in Table.

Table. Primer sequences for qRT-PCR.

\begin{tabular}{lc}
\hline Gene & \multicolumn{1}{c}{ Sequence } \\
\hline PDGF & R:ATGGCATGCAAGTGTGAGAC \\
& F:CACACAGGATGGCTTGAAGA \\
VEGF & R:AGGGCAGAATCATCACGAAG \\
& R:GAAGATGATGGAGTAGATGG \\
CXCR4 & R:GATGCTGGCGCTGAGTACG \\
& R:GCTAAGCAGTTGGTGGTGC \\
\hline
\end{tabular}

\section{Western blotting}

DPCs were cultured with cell culture media with $2 \%, 5 \%$, and $10 \%$ CGFe and without CGFe. After $24 \mathrm{~h}$ of culture, the cell samples were lysed in RIPA lysis buffer (Beyotime, China). Protein concentrations were measured using a BCA protein kit (Beyotime, China). Twenty microliters of protein was loaded per lane on a 10\% SDS-PAGE gel for electrophoresis and then transferred to $0.22 \mathrm{~mm}$ PVDF membranes (Bio-Rad, USA). Western blot analysis was performed as described previously. ${ }^{15}$

\section{Statistical analysis}

Data were calculated and expressed as the mean and standard error. Statistical analysis was performed using SPSS 22.0 software. Statistical significance was evaluated by using one-way analysis of variance (ANOVA) followed by Tukey's multiple comparison test. A p-value $<0.05$ was considered significant.

\section{Results}

\section{Effects of CGFe on cell proliferation in DPCs}

DPCs cultured with CGFe had significantly higher proliferation rates than the control group $(p<0.05)$ (Figure 1A). Higher concentrations ( $\leq 10 \%)$ of CGFe allowed faster cell growth; however, the 15\% CGFe concentration showed the same proproliferative effects as $10 \%$ CGFe at all time points ( $p>0.05)$. Thus, the 15\% CGFe group was not used in the other assays.

The cell cycle assay showed that G2/M phase cell ratio significantly increased after culture with CGFe $(p<0.05)$ (Figure 1B). The cell proliferation capacities of the different groups on were as follows: control group $<2 \%$ CGFe group $<5 \%$ CGFe group $<10 \%$ CGFe group.

\section{Effects of CGFe on HUVEC proliferation and migration}

HUVEC proliferation and migration are two key aspects of revascularization. The CCK-8 assay showed that HUVECs had higher proliferation rates after CGFe treatment at all measured time point and that the higher concentrations allowed faster cell growth (Figure 2A, $\mathrm{p}<0.05$ ). Representative images of transwell 

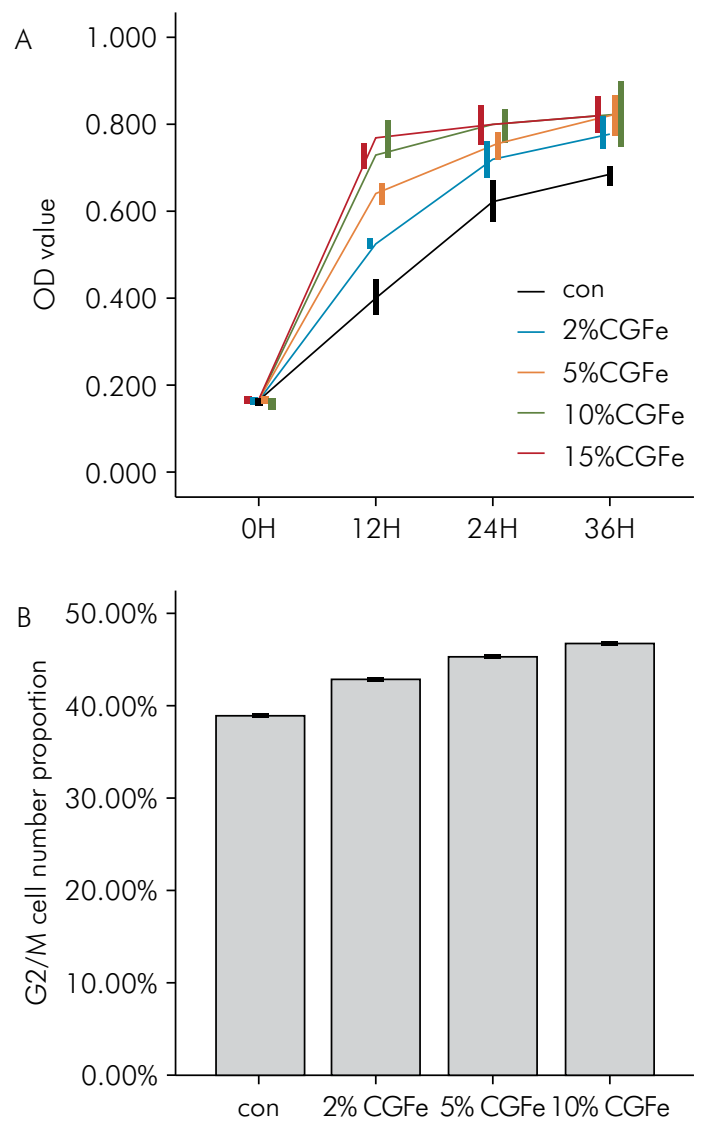

Figure 1. Effects of CGFe on cell proliferation in DPCs. (A) CGFe significantly promoted DPC proliferation in a dosedependent manner at concentrations $\leq 10 \%(p<0.05)$. However, 15\% CGFe showed no difference in promoting effects compared with 10\% CGFe ( $p>0.05)$. (B) Effect of CGFe on the cell cycle of DPCs. CGFe played a positive role in promoting cell proliferation. All data are presented as the mean \pm SE of three independent experiments.

assay are shown in Figure $2 \mathrm{~B}$ and the results showed that CGFe promoted HUVECs migration at $2 \%, 5 \%$, $10 \%$ concentrations and the enhancement peaked at $10 \%$ (Figure $2 \mathrm{C}, \mathrm{p}<0.05$ ). This result indicated that the proproliferative and promigratory effects of CGFe were dose dependent for concentrations of $\leq 10 \%$.

\section{Effects of CGFe on in vitro tube formation}

The cells seeded on matrigel began to form vessellike structures after $4 \mathrm{~h}$. Treatment with CGFe led to a significant increase in the quantity of tube formation compared with that in the control group and had a positive dose-dependent effect on vessel-like structure formation $(p<0.05)$ (Figure 3).

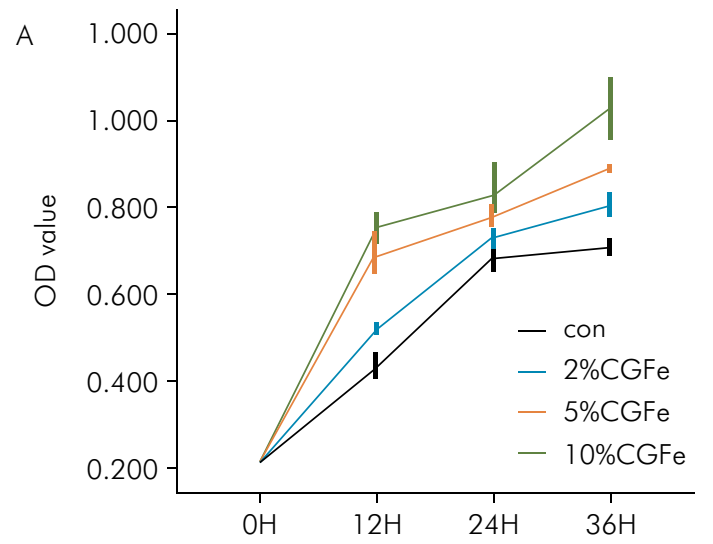

B

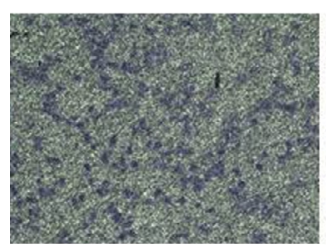

con

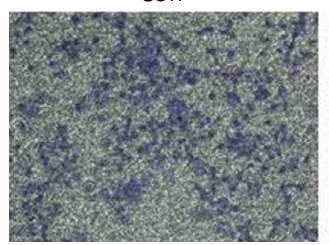

$5 \%$ CGFe

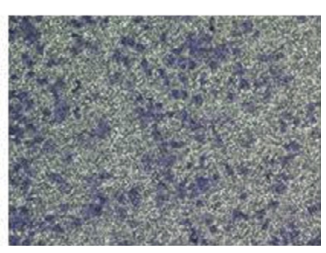

$2 \%$ CGFe

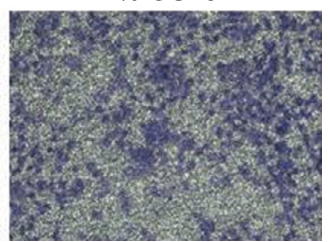

$10 \%$ CGFe

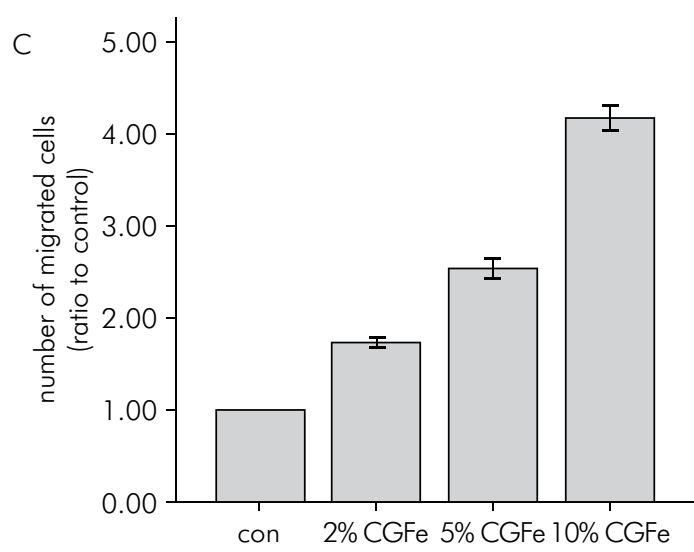

Figure 2. Effects of CGFe on the cell proliferation and migration of HUVECs. (A) CGFe significantly accelerated HUVEC proliferation in a dose-dependent manner at concentrations $\leq 10 \%(p<0.05)$. (B) Representative images for each group are shown above. (C) Quantification of migrated cells. As suggested, CGFe also promoted HUVEC migration in a dose-dependent manner $(p<0.05)$. All data are presented as the mean \pm SE of three independent experiments. 
A

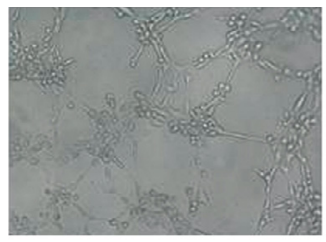

con

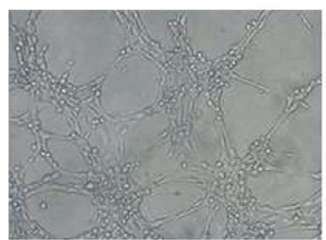

$5 \%$ CGFe

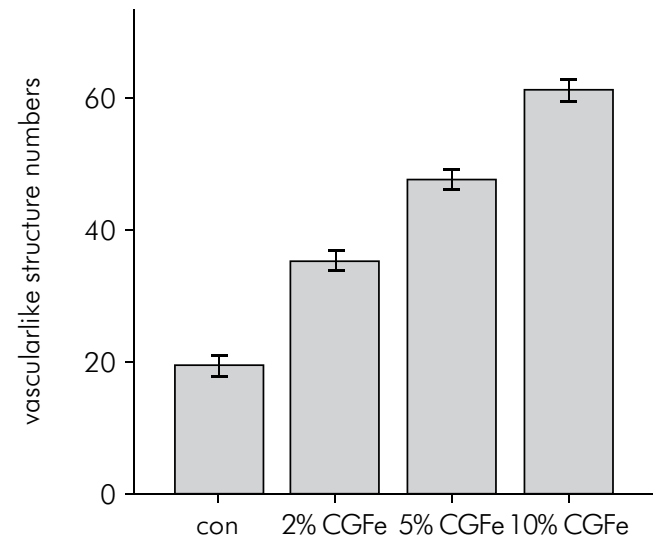

Figure 3. Effects of CGFe on in vitro angiogenesis. Cell mixtures were incubated in a matrigel-coated 96-well plate, and samples were photographed using a digital imaging system $6 \mathrm{~h}$ after seeding. (A) Representative images are shown above. (B) Tube numbers were quantified using Image Pro Plus 6.0. CGFe promoted vessel-like structure formation in a dosedependent manner $(p<0.05)$. All data are presented as the mean \pm SE of three independent experiments.

\section{Effects of CGFe on the PDGF, CXCR4 and VEGF mRNA levels of DPCs}

To explore the effect of CGFe treatment on DPCs at the mRNA level, we compared the mRNA expression of PDGF, CXCR4, and VEGF using RT-PCR. The mRNA expression levels of PDGF, CXCR4, and VEGF in the experimental group were upregulated compared with those in the control group, and the expression increased in a positive dose-dependent manner $(p<0.05)$ (Figure 4).

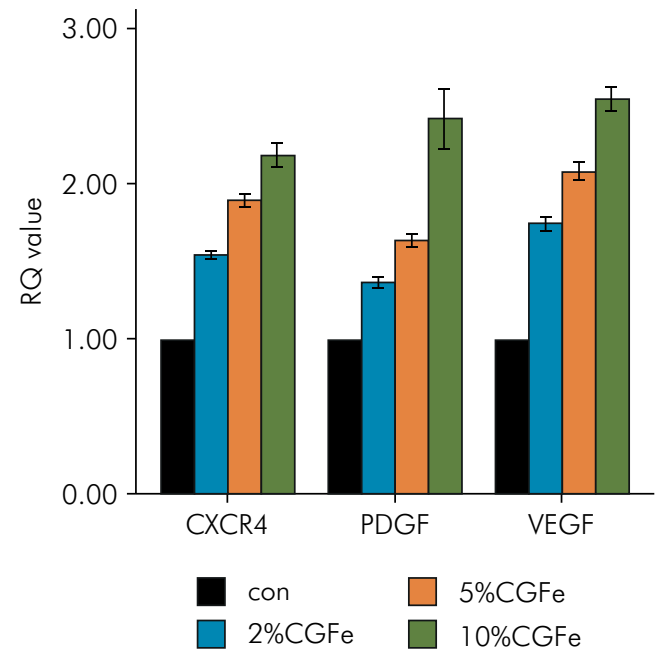

Figure 4. Expression levels of CXCR4, PDGF and VEGF after $24 \mathrm{~h}$ of culture. The mRNA expression levels of DPCs were evaluated by RT-PCR. The expression levels of CXCR4 and VEGF were normalized to the GAPDH expression. The results showed a rising trend in the 2\% CGFe, 5\% CGFe and 10\% CGFe groups compared with the control group. All data are presented as the mean \pm SE of three independent experiments.

\section{Effects of CGFe on the levels of related proteins in DPCs}

The VEGF and CXCR4 protein levels in DPCs were determined by Western blot. The expression levels of both VEGF and CXCR4 in the three experimental groups were upregulated after $24 \mathrm{~h}$ compared with those in the control group, and these expression levels also increased in a positive dose-dependent manner $(\mathrm{p}<0.05)$ (Figure 5).

\section{Discussion}

Concentrated growth factor (CGF), a kind of fibrin plasma rich in growth factors, has been clinically shown to accelerate tissue healing in many fields, such as bone reconstruction, angiogenesis, dental implants and other types of tissue remodeling. The platelets in CGF are 15.5 times as concentrated as in those in whole blood according to Masuki et al. CGF contains high concentrations of growth factors, including PDGF, VEGF, and CXCR4. VEGF is the most potent cytokine involved in angiogenesis. ${ }^{15}$ The regulation of VEGF is critical to neovascularization in numerous tissues under both physiological and pathological conditions. ${ }^{16}$ Studies showed that 
A
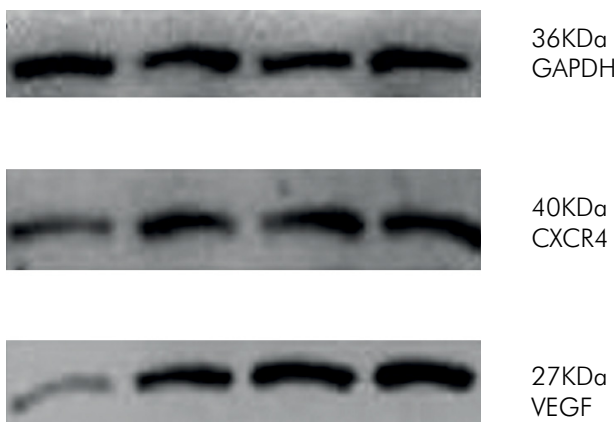

con $2 \%$ CGFe $5 \%$ CGFe $10 \%$ CGFe

B

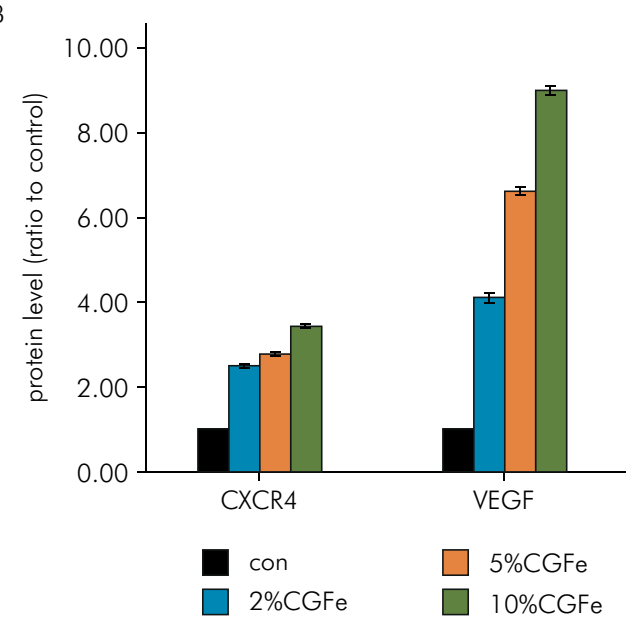

Figure 5. Expression levels of CXCR4 and VEGF determined by Western blotting. Western blot analysis showed that CGFe upregulated the CXCR4 and VEGF protein expression levels. (A) Representative images of three independent experiments are shown above. (B) Bands were quantified using Gel-Pro Analyzer 4.0(Sigma-Aldrich, USA). The expression of VEGF and CXCR4 rose in a positive dose-dependent manner $(p<0.05)$.

VEGF played a key role in the differentiation of dental pulp stem cells into endothelial cells. ${ }^{17}$ VEGF also promotes the survival and proliferation of endothelial cells and the sprouting and permeability of vessels. ${ }^{16,18,19}$ In addition, CXCR4 was also proved to play an important role ${ }^{20}$ in regulating angiogenesis through interaction with its ligand, CXCL-12, ${ }^{21,22,23}$ by recruiting endothelial progenitor cells. ${ }^{24,25,26} \mathrm{PDGF}$, a powerful angiogenic growth factor, had synergistic and composite effects with other cytokines involved in the angiogenic effects. ${ }^{27} \mathrm{~A}$ study by Zhang et al. ${ }^{28}$ proved that PDGF possesses the powerful function of inducing dentin-pulp tissue regeneration by dental pulp stem cells. Therefore, we speculated that these growth factors in CGF will promote dental pulp revascularization.

DPCs are considered the main cells for regenerative endodontics. ${ }^{29,30,31}$ Some living DPCs still exist in the apical region of dental pulp even in teeth that suffer from irreversible pulpitis. DPCs were also demonstrated to interact with endothelial cells to enhance angiogenic effects in vitro. ${ }^{31,32,33}$ Endothelial cell proliferation and migration are essential events during angiogenesis. ${ }^{15}$ Therefore, the proliferation and differentiation of DPCs and the proliferation, migration and vascular structure formation capacity of HUVECs were evaluated in our experiment. Based on the results of our study, CGFe elevated the VEGF, PDGF and CXCR4 expression of DPCs, promoted HUVEC proliferation and migration and augmented vascular structure formation, suggesting that CGF plays a significant positive role in dental pulp revascularization.

However, higher concentrations of CGFe do not guarantee stronger promoting effects. In our study, CGFe at concentrations $\leq 10 \%$ promoted cell proliferation and enhanced angiogenesis in a dose-dependent manner. However, 15\% CGFe showed the same effect on DPC proliferation as $10 \%$ CGFe at all time points ( $p>0.05)$, suggesting that the promoting effects of CGFe depend on the concentration used. In a study by Honda et al., ${ }^{34}$ CGFe at concentrations below $10 \%$ promoted the proliferation and maturation of human bone marrow stromal cells in a dose-dependent manner but had an inhibitory effect at a $20 \%$ concentration. An in vitro experiment by Masuki et al. ${ }^{10}$ suggested that the proproliferative and promigratory effects of CGFe on periosteal cells peaked at a $10 \%$ concentration and that the effects were reversed at a $20 \%$ concentration. In study by Qiao et al., ${ }^{35}$ the optimum concentration for human periodontal ligament cell proliferation was medium rather than high. A reasonable explanation for this phenomenon might be that CGFe contains not only growth factors that favor revascularization but also 
antiangiogenic cytokines. ${ }^{36}$ At high concentrations, the inhibitory effects of the inflammatory cytokines in CGF might play a dominant role. Previous studies also demonstrated that platelets store proangiogenic and antiangiogenic regulators in separate granules and differentially release these factors in response to different stimuli. ${ }^{37,38,39,40}$ Thus, the CGF state may affect the angiogenic capacity of CGF under different conditions, which needs to be further studied.

Based on the results of the present study, CGF shows positive proangiogenic effects on DPCs and HUVECs, which may be an indication of its applicative potential for inducing dental pulp revascularization. The effectiveness of CGF application in dental pulp revascularization needs to be investigated in in vivo studies in the future.

\section{References}

1. Wigler R, Kaufman AY, Lin S, Steinbock N, Hazan-Molina H, Torneck CD. Revascularization: a treatment for permanent teeth with necrotic pulp and incomplete root development. J Endod. 2013 Mar;39(3):319-26. https://doi.org/10.1016/i.joen.2012.11.014

2. Huang GT. Dental pulp and dentin tissue engineering and regeneration: advancement and challenge. Front Biosci (Elite Ed). 2011 Jan;3(2):788-800. https://doi.org/10.2741/e286

3. Jeeruphan T, Jantarat J, Yanpiset K, Suwannapan L, Khewsawai P, Hargreaves KM. Mahidol study 1: comparison of radiographic and survival outcomes of immature teeth treated with either regenerative endodontic or apexification methods: a retrospective study. J Endod. 2012 Oct;38(10):1330-6. https://doi.org/10.1016/i.joen.2012.06.028

4. Banchs F, Trope M. Revascularization of immature permanent teeth with apical periodontitis: new treatment protocol? J Endod. 2004 Apr;30(4):196-200. https://doi.org/10.1097/00004770-200404000-00003

5. Ding RY, Cheung GS, Chen J, Yin XZ, Wang QQ, Zhang CF. Pulp revascularization of immature teeth with apical periodontitis: a clinical study. J Endod. 2009 May;35(5):745-9. https://doi.org/10.1016/i.joen.2009.02.009

6. Nosrat A, Homayounfar N, Oloomi K. Drawbacks and unfavorable outcomes of regenerative endodontic treatments of necrotic immature teeth: a literature review and report of a case. J Endod. 2012 Oct;38(10):1428-34. https://doi.org/10.1016/i.joen.2012.06.025

7. Torabinejad M, Faras $\mathrm{H}$. A clinical and histological report of a tooth with an open apex treated with regenerative endodontics

\section{Conclusions}

Our study demonstrated that CGF promoted DPC proliferation and differentiation and promoted HUVEC proliferation, migration and vessel-like structure formation.

\section{Acknowledgments}

This work was supported in part by the Natural Science Foundation of China (31371473, 31571508). I want to express heartfelt thanks for the support from the Chongqing Key Laboratory of Oral Diseases and Biomedical Sciences, Chongqing Medical University and to all the research workers with whom we worked. I also wish to express my gratitude to my tutor, Professor Yang, and all the researchers in the laboratory for their generous support and helpful advice.

using platelet-rich plasma. J Endod. 2012 Jun;38(6):864-8.

https://doi.org/10.1016/i.joen.2012.03.006

8. Jadhav G, Shah N, Logani A. Revascularization with and without platelet-rich plasma in nonvital, immature, anterior teeth: a pilot clinical study. J Endod. 2012 Dec;38(12):1581-7. https://doi.org/10.1016/i.joen.2012.09.010

9. Jadhav GR, Shah N, Logani A. Comparative outcome of revascularization in bilateral, non-vital, immature maxillary anterior teeth supplemented with or without platelet rich plasma: A case series. J Conserv Dent. 2013 Nov;16(6):568-72. https://doi.org/10.4103/0972-0707.120932

10. Masuki H, Okudera T, Watanebe T, Suzuki M, Nishiyama K, Okudera $\mathrm{H}$ et al. Growth factor and pro-inflammatory cytokine contents in platelet-rich plasma (PRP), plasma rich in growth factors (PRGF), advanced platelet-rich fibrin (A-PRF), and concentrated growth factors (CGF). Int J Implant Dent. 2016 Dec;2(1):19. https://doi.org/10.1186/s40729-016-0052-4

11. Qin J, Wang L, Zheng L, Zhou X, Zhang Y, Yang $T$ et al. Concentrated growth factor promotes Schwann cell migration partly through the integrin $\beta 1$-mediated activation of the focal adhesion kinase pathway. Int J Mol Med. 2016 May;37(5):1363-70. https://doi.org/10.3892/ijmm.2016.2520

12. Sohn DS, Heo JU, Kwak DH, Kim DE, Kim JM, Moon JW et al. Bone regeneration in the maxillary sinus using an autologous fibrin-rich block with concentrated growth factors alone. Implant Dent. 2011 Oct;20(5):389-95. https://doi.org/10.1097/ID.0b013e31822f7a70. 
13. Kobayashi M, Kawase T, Horimizu M, Okuda K, Wolff LF, Yoshie $\mathrm{H}$. A proposed protocol for the standardized preparation of PRF membranes for clinical use. Biologicals. 2012 Sep;40(5):323-9. https://doi.org/10.1016/j.biologicals.2012.07.004

14. Ma D, Gao J, Yue J, Yan W, Fang F, Wu B. Changes in proliferation and osteogenic differentiation of stem cells from deep caries in vitro. J Endod. 2012 Jun;38(6):796-802. https://doi.org/10.1016/i.joen.2012.02.014

15. Zheng LC, Wang XQ, Lu K, Deng XL, Zhang CW, Luo H et al. Ephrin-B2/Fc promotes proliferation and migration, and suppresses apoptosis in human umbilical vein endothelial cells. Oncotarget. 2017 Jun;8(25):41348-63. https://doi.org/10.18632/oncotarget.17298

16. Vempati P, Popel AS, Mac Gabhann F. Extracellular regulation of VEGF: isoforms, proteolysis, and vascular patterning. Cytokine Growth Factor Rev. 2014 Feb;25(1):1-19. https://doi.org/10.1016/j.cytogfr.2013.11.002

17. Saghiri MA, Asatourian A, Sorenson CM, Sheibani N. Role of angiogenesis in endodontics: contributions of stem cells and proangiogenic and antiangiogenic factors to dental pulp regeneration. J Endod. 2015 Jun;41(6):797-803. https://doi.org/10.1016/i.joen.2014.12.019

18. Shibuya M. Vascular endothelial growth factor and its receptor system: physiological functions in angiogenesis and pathological roles in various diseases. J Biochem. 2013 Jan;153(1):13-9. https://doi.org/10.1093/jb/mvs136

19. Moens S, Goveia J, Stapor PC, Cantelmo AR, Carmeliet P. The multifaceted activity of VEGF in angiogenesis - Implications for therapy responses. Cytokine Growth Factor Rev. 2014 Aug;25(4):473-82. https://doi.org/10.1016/j.cyłogfr.2014.07.009

20. Jin DK, Shido K, Kopp HG, Petit I, Shmelkov SV, Young LM et al. Cytokine-mediated deployment of SDF-1 induces revascularization through recruitment of CXCR4+ hemangiocytes. Nat Med. 2006 May;12(5):557-67. https://doi.org/10.1038/nml400

21. Zou YR, Kottmann AH, Kuroda M, Taniuchi I, Littman DR. Function of the chemokine receptor CXCR4 in haematopoiesis and in cerebellar development. Nature. 1998 Jun;393(6685):595-9. https://doi.org/10.1038/31269

22. Petit I, Szyper-Kravitz M, Nagler A, Lahav M, Peled A, Habler $L$ et al. G-CSF induces stem cell mobilization by decreasing bone marrow SDF-1 and up-regulating CXCR4. Nat Immunol. 2002 Jul;3(7):687-94. https://doi.org/10.1038/ni813

23. Avecilla ST, Hattori K, Heissig B, Tejada R, Liao F, Shido K et al. Chemokine-mediated interaction of hematopoietic progenitors with the bone marrow vascular niche is required for thrombopoiesis. Nat Med. 2004 Jan;10(1):64-71. https://doi.org/10.1038/nm973

24. Ceradini DJ, Kulkarni AR, Callaghan MJ, Tepper OM, Bastidas $\mathrm{N}$, Kleinman ME et al. Progenitor cell trafficking is regulated by hypoxic gradients through HIF-1 induction of SDF-1. Nat Med. 2004 Aug;10(8):858-64. https://doi.org/10.1038/nm1075

25. De Falco E, Porcelli D, Torella AR, Straino S, lachininoto MG, Orlandi A et al. SDF-1 involvement in endothelial phenotype and ischemia-induced recruitment of bone marrow progenitor cells. Blood. 2004 Dec;104(12):3472-82. https://doi.org/10.1182/blood-2003-12-4423

26. Walter DH, Haendeler J, Reinhold J, Rochwalsky U, Seeger F, Honold J et al. Impaired CXCR4 signaling contributes to the reduced neovascularization capacity of endothelial progenitor cells from patients with coronary artery disease. Circ Res. 2005 Nov; 97(11):1142-51. https://doi.org/10.1161/01.RES.0000193596.94936.2c

27. Kakudo N, Morimoto N, Kushida S, Ogawa T, Kusumoto K. Platelet-rich plasma releasate promotes angiogenesis in vitro and in vivo. Med Mol Morphol. 2014 Jun;47(2):83-9. https://doi.org/10.1007/s00795-013-0045-9

28. Zhang $M$, Jiang $F$, Zhang $X$, Wang S, Jin $Y$, Zhang W et al. The effects of platelet-derived growth factor-bb on human dental pulp stem cells mediated dentin-pulp complex regeneration. Stem Cells Transl Med. 2017 Dec;6(12):2126-34. https://doi.org/10.1002/sctm.17-0033

29. Gronthos S, Mankani M, Brahim J, Robey PG, Shi S. Postnatal human dental pulp stem cells (DPSCs) in vitro and in vivo. Proc Natl Acad Sci USA. 2000 Dec;97(25):13625-30. https://doi.org/10.1073/pnas.240309797

30. Gronthos S, Brahim J, Li W, Fisher LW, Cherman N, Boyde $A$ et al. Stem cell properties of human dental pulp stem cells. J Dent Res. 2002 Aug;81(8):531-5. https://doi.org/10.1177/154405910208100806

31. Dissanayaka WL, Zhu L, Hargreaves KM, Jin L, Zhang C. In vitro analysis of scaffold-free prevascularized microtissue spheroids containing human dental pulp cells and endothelial cells. J Endod. 2015 May;41(5):663-70. https://doi.org/10.1016/i.joen.2014.12.017

32. Shi S, Gronthos S. Perivascular niche of postnatal mesenchymal stem cells in human bone marrow and dental pulp. J Bone Miner Res. 2003 Apr;18(4):696-704. https://doi.org/10.1359/jbmr.2003.18.4.696

33. Dissanayaka WL, Zhan X, Zhang C, Hargreaves KM, Jin L, Tong EH. Coculture of dental pulp stem cells with endothelial cells enhances osteo-/odontogenic and angiogenic potential in vitro. J Endod. 2012 Apr;38(4):454-63. https://doi.org/10.1016/i.joen.2011.12.024

34. Honda H, Tamai N, Naka N, Yoshikawa H, Myoui A. Bone tissue engineering with bone marrow-derived stromal cells integrated with concentrated growth factor in Rattus norvegicus calvaria defect model. J Artif Organs. 2013 Sep;16(3):305-15. https://doi.org/10.1007/s10047-013-0711-7

35. Qiao J, An N. Effect of concentrated growth factors on function and Wnt3a expression of human periodontal ligament cells in vitro. Platelets. 2017 May;28(3):281-6. https://doi.org/10.1080/09537104.2016.1213381

36. Dohan DM, Choukroun J, Diss A, Dohan SL, Dohan AJ, Mouhyi J et al. Platelet-rich fibrin (PRF): a second-generation platelet concentrate. Part III: leucocyte activation: a new feature for platelet concentrates? Oral Surg Oral Med Oral Pathol Oral Radiol Endod. 2006 Mar;101(3):e51-5. https://doi.org/10.1016/j.tripleo.2005.07.010 
37. Ma L, Perini R, McKnight W, Dicay M, Klein A, Hollenberg $M D$ et al. Proteinase-activated receptors 1 and 4 counterregulate endostatin and VEGF release from human platelets. Proc Natl Acad Sci USA. 2005 Jan;102(1):216-20. https://doi.org/10.1073/pnas.0406682102

38. Italiano JE Jr, Richardson JL, Patel-Hett S, Battinelli E, Zaslavsky A, Short $\mathrm{S}$ et al. Angiogenesis is regulated by a novel mechanism: pro- and antiangiogenic proteins are organized into separate platelet alpha granules and differentially released. Blood. 2008 Feb;111(3):1227-33. https://doi.org/10.1182/blood-2007-09-113837
39. Chatteriee M, Huang Z, Zhang W, Jiang L, Hultenby K, Zhu $L$ et al. Distinct platelet packaging, release, and surface expression of proangiogenic and antiangiogenic factors on different platelet stimuli. Blood. 2011 Apr;117(14):3907-11. https://doi.org/10.1182/blood-2010-12-327007

40. Huang Z, Miao X, Luan Y, Zhu L, Kong F, Lu Q et al. PAR1stimulated platelet releasate promotes angiogenic activities of endothelial progenitor cells more potently than PAR4-stimulated platelet releasate.

J Thromb Haemost. 2015 Mar;13(3):465-76. https://doi.org/10.1111/jth.12815 